\title{
Dinamika Populasi dan Produktivitas Sapi Madura di Wilayah Konservasi Pulau Sapudi
}

\author{
F. Kutsiyah \\ Jurusan Ekonomi dan Bisnis Islam STAIN Pamekasan
}

\begin{abstract}
ABSTRAK
Penelitian dilaksanakan untuk mengetahui dinamika populasi, produktivitas, dan output sapi Madura di wilayah Konservasi Pulau Sapudi, Sumenep. Jumlah responden sebanyak 108 orang dengan 361 ekor sapi Madura dan diambil dari enam (6) desa. Teknik pengambilan sampel menggunakan axidental sampling dan data dihitung dengan analisis diskriptif. Hasil penelitian menunjukkan bahwa S/C 1,68 $\pm 0,87$ kali, jarak beranak 14,56 $\pm 2,15$ bulan, dan nilai efisiensi reproduksi (ER) 93,21\%. Nilai natural increase (NI) sapi Madura di Pulau Sapudi tahun 2014 sebesar 27,96\%, nilai net replacement rate (NRR) sapi jantan dan betina masing-masing sebesar 96,18 \% dan 126,41\%. Hasil estimasi output sapi PO 30,75\%. Estimasi dinamika populasinya tahun 2015 sampai 2019 diperkirakan akan menurun 599 ekor atau -0,09\% per tahun. Disimpulkan bahwa di Pulau Sapudi telah terjadi pengurasan populasi dan jumlah kebutuhan ternak pengganti sapi jantan tidak terpenuhi. Oleh karena itu tindakan selayaknya dilakukan adalah mengurangi pengeluaran ternak khususnya sapi jantan dan menyediakan infrastruktur yang mendukung hal tersebut, salah satunya yang paling dibutuhkan saat ini adalah ketersediaan infrastruktur pakan dan infrastruktur yang mendukung ketersediaan air.
\end{abstract}

Kata kunci: Dinamika populasi, Produktivitas, Pulau Sapudi, Sapi Madura

\section{Population Dynamic and productivity of Madura Cattle in Corservation Area of Sapudi Island}

\section{ABSTRACT}

The study was conducted to determine population dynamic, productivity, and output of Madura cattle in a conservation area of Sapudi Island. The number of respondents was 108 farmers and 361 heads of madura cattle taken from six (6 villages). The sampling technique used accidental sampling method and data was counted by descriptive analysis. The results showed

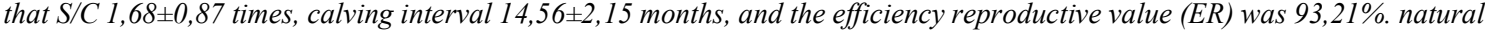
increase (NI) value of Madura cattle in Sapudi Island in 2014 was 27.96\%. Net replacement rate (NRR) value of sire and dam of cattle were $96,18 \%$ dan 126,41\% respectively. Output estimation was 30,75\% population dynamic of maduracattle in 2015 to 2019 has estimated that will be decreased 566 heads or $-0.09 \%$ per year. It was concluded that the population in Sapudi Island has been dumped and the need for replacement bulls is not fulfilled. Therefore action should be taken to reduce the expenditure of livestock, especially bulls and provide the supporting infrastructure which supports it, one of the most required right now is the availability of feed and water infrastructure.

Keywords: Madura cattle, Population dynamic, Productivity, Sapudi Island

\section{PENDAHULUAN}

Pulau Sapudi adalah kawasan yang dikonsentrasikan sebagai wilayah pemurnian plasma nutfah sapi Madura, dengan kapasitas \pm 5000 ekor (Deptan, 1998). Ditjen Peternakan dan Kesehatan Hewan pada tanggal 20 Juni 2012 menetapkan kawasan tersebut sebagai daerah konservasi bagi pemurnian plasma nutfah (sumberdaya genetik) sapi Madura. Luas wilayah Pulau Sapudi mencapai 128.53 $\mathrm{km}^{2}$ yang mencakup dua kecamatan yakni Gayam dan Nonggunong dengan 18 desa. Curah hujan termasuk tipe $\mathrm{D}$ atau kering ( $1.250-1.500 \mathrm{~mm}$ per tahun) dengan temperatur mencapai $27^{\circ}$ hingga $35^{\circ} \mathrm{C}$. Jumlah penduduk tahun 2015 mencapai 47.144 jiwa dengan jumlah KK sebesar 18.646 (Dispet Provinsi Jatim, 2013; BPS, 2016a;2016b).

Pulau Sapudi disebut juga sebagai pulau sapi dan dikenal sebagai sumber bibit sapi kerap. Karakter

\footnotetext{
*Penulis Korespondensi: F. Kutsiyah

Alamat: Jalan Raya Panglegur KM. 4, Tlanakan, Ceguk, Kec.

Pamekasan, Kabupaten Pamekasan, Jawa Timur 69371

E-mail: keindahanmaduraku@gmail.com
}

wilayah ini khas terlekat dengan sapi dengan populasinya mendekati jumlah penduduk, dimana setiap KK memiliki 2 hingga 10 ekor. Hasil survey tahun 2011 populasi sapi sebanyak 39.997 ekor atau $303 \mathrm{ekor} / \mathrm{km}^{2}$ (Dispet, 2014), dengan pengeluaran ternak sekitar 4.000-8.000 ekor per tahun. Sementara data hasil sensus pertanian tahun 2013 populasinya meningkat menjadi 41.371 ekor (BPS, 2013) dan populasi tahun 2015 mengalami penurunan menjadi 40.121 ekor (BPS, 2016). Sebagai penjelasan bangsa sapi yang ada di Pulau ini hampir seluruhnya sapi Madura, Kutsiyah (2012b) menyebutkan Pulau konservasi tersebut masih ditemukan sapi ongole dengan jumlah puluhan ekor $(\leq 100$ ekor) yang terkonsentrasi di Desa Prambanan.

FAO (1995; European Commission Union, 1992) merekomendasikan untuk melindungi dari kepunahan melalui perencanaan konservasi genetik dengan pemanfaatan dan konservasi sumberdaya genetik yang lebih baik. Merujuk hal tersebut, evaluasi perkembangan populasi ternak sapi Madura di wilayah konservasi Pulau Sapudi ini perlu dilakukan. Oleh karena sebagai tujuan penelitian ini untuk mengetahui 
dinamika populasi, produktivitas, dan output sapi Madura di Pulau Sapudi.

\section{MATERI DAN METODE}

\section{Materi}

Materi yang digunakan dalam penelitian ini adalah peternak sapi Madura di Pulau sapudi. Jumlah responden 108 orang, dengan jumlah sapi 361 ekor yang diambil dari 6 desa (Desa Sokarame Timur, Talagah, Sonok, Gayam, Pancor dan Prambanan) masing-masing setiap kecamatan 3 desa. Peralatan yang digunakan dalam penelitian ini adalah tape recorder, kamera, dan alat tulis menulis.

\section{Metode}

Sistem pengambilan data dilakukan dengan wawancara langsung kepada petani peternak (responden) dengan menggunakan kuisioner. Desa yang menjadi target populasi ada 18, yakni 6 Desa dari Kecamatan Nonggunong dan 10 Desa dari Kecamatan Gayam. Penentuan desa dipilih secara acak, sementara untuk penentuan responden dengan menggunakan axidental sampling, teknik non probability sampling ini dilakukan karena tidak adanya data peternak di masingmasing desa.

\section{Analisis Data}

Data yang diperoleh disajikan dalam bentuk rataan, standart deviasi dan prosentase. Untuk dinamika populasi dianalisis dengan time series, sementara output sapi Madura dianalisis dengan teori pemuliabiakan ternak.

Penghitungan Natural increase (NI) adalah persentase kelahiran pertahun - persentase kematian pertahun. Nilai net replacement rate (NRR) diperoleh dari perbandingan jumlah ternak muda calon pengganti dibagi dengan kebutuhan ternak pengganti pertahun dikalikan 100\% (Sumadi et al., 2001). Nilai efisiensi reproduksi (ER) dihitung dengan rumus sebagai berikut (Kusuma et al., 2017):

$$
\mathrm{ER}=\frac{a \times b}{(c)-(d)+(a-e)} \times 100 \%
$$

Keterangan :

a: Jarak beranak

b: Jumlah anak beranak)

c: Induk I beranak (umur induk pertama kali

$\mathrm{d}$ : induk 1 kawin (umur induk pertama kali kawin) e: lama bunting

Output populasi dihitung berdasarkan jumlah ternak yang tersingkir tiap tahun ditambah sisa ternak pengganti. Dinamika populasi diestimasi dari data populasi sapi potong di Pulau Sapudi enam tahun terakhir (2009-2014) kemudian dianalisis time series dengan persamaan garis linier.

$\mathrm{Y}=\mathrm{aX}+\mathrm{b}$

Keterangan :

$$
\begin{aligned}
& \mathrm{Y}=\text { data berjangka (time series data) } \\
& \mathrm{X}=\text { waktu (tahun ke-) } \\
& \mathrm{a}=\text { koefisien regresi, } \\
& \mathrm{b}=\text { intersep }
\end{aligned}
$$

\section{HASIL DAN PEMBAHASAN}

\section{Penampilan Reproduksi}

Hasil pendataan terhadap 361 ekor sapi, penampilan reproduksi sapi Madura di Pulau Sapudi tahun 2014 tersaji pada Tabel 1. Rata-rata umur pertama kali kawin sapi betina $21,12 \pm 0,16$ bulan. Hasil ini lebih pendek dibandingkan dengan penelitian Wisono (2015) yakni umur pertama kawin sapi Madura induk di Kabupaten Pamekasan masing-masing kecamatan Tlanakan, Pegantenan dan Pasean secara berurutan adalah $23,79 \pm 2,53$ bulan; $23,06 \pm 2,86$ bulan; dan $23,48 \pm 2,31$ bulan. Adapun rataan umur pertama kali kawin sapi jantan di Pulau Sapudi 28,92 $\pm 0,26$ bulan. Senada dengan hasil penelitian Hardjosubroto et al. (1993) yang menyebutkan umur pertama kali dikawinkan pada sapi jantan adalah $2,6 \pm 0,1$ tahun.

Service per conception (S/C) mencapai 1,68 $\pm 0,87$. Hasil ini lebih rendah dengan Wisono (2015) S/C sapi Madura dengan IB pada tiga titik lokasi di Madura yaitu $1,43 \pm 0,68$ kali; $1,28 \pm 0,45$ kali dan $1,1 \pm 0,30$ kali. Lebih lanjut pengamatan Efendy et al. (2013) melalui penerapan kawin alam sebanyak 79,57\% dari sampel diperoleh sapi betina berhasil bunting hanya dengan satu kali kawin. Jarak beranak 14,56 $\pm 2,15$ bulan. Calving interval ini lebih lama dibandingkan laporan Wisono (2015) yakni di tiga kecamatan di Kabupaten Pamekasan yakni $434,05 \pm 35,62$ hari; $384,97 \pm 27,45$ hari and 374,32 $\pm 17,85$ hari. Sementara itu, diperoleh informasi bahwa umur pertama beranak 31,97 $\pm 6,43$ bulan. Hasil pengamatan tersebut mengindetifikasiumur pertama beranak di Pulau sapudi dibandingkan di Pamekasan 34,63 $\pm 2,46$ bulan (Wisono, 2015).

Batas umur pemeliharaan sapi jantan sangat muda sekali yakni $0,55 \pm 0,61$ tahun, kondisi sebaliknya dengan batas umur pemeliharaan sapi betina mencapai $11,29 \pm 4,92$ tahun. Hasil ini berbeda dengan di luar Sapudi, Hardjosubroto et al. (1993) menyebutkan bahwa sapi jantan dipelihara sampai umur $4,1 \pm 0,2$ tahun, sedang betina 7,6 $\pm 0,3$ tahun atau beranak sampai $4,6 \pm 0,3$ kali. Jika diperhitungkan antara umur pertama kali dikawinkan sampai saat disingkirkan dari pembiakan, berarti sapi betina dapat beranak sampai lima kali, tetapi jika dilihat atasdasar jumlah anak terlahir selama pembiakan diduga dipelihara sampai umur 7-8 tahun.

Nilai Efisiensi produksi (ER) sapi di wilayah konservasi sapi Madura diperoleh yaitu 93,21\% tergolong relatif rendah, hal ini disebabkan karena umur pertama kali beranak yang masih terlalu lama. Sumadi (1993, dalam Kusuma et al., 2017) Induk yang beranak pertama kali lebih dari 27 bulan akan mempunyai nilai ER kurang dari $100 \%$ dan sebaliknya 
Tabel 1. Penampilan reproduksi sapi Madura di Pulau Sapudi

\begin{tabular}{|c|c|}
\hline Uraian & Rataan \\
\hline \multicolumn{2}{|l|}{ 1. $\quad$ Umur pertama kali kawin (Bulan) } \\
\hline - Jantan & $19,25 \pm 5,50$ \\
\hline - Betina & $21,91 \pm 5,73$ \\
\hline 2. $\mathrm{S} / \mathrm{C}$ (Kali) & $1,68 \pm 0,87$ \\
\hline 3. Umur penyapihan (bulan) & $5,06 \pm 0,88$ \\
\hline \multicolumn{2}{|l|}{ 4. Batas umur pemeliharaan (tahun) } \\
\hline- Jantan & $0,55 \pm 0,61$ \\
\hline - $\quad$ Betina & $11,29 \pm 4,92$ \\
\hline \multicolumn{2}{|l|}{ 5. Lama dalam pembiakan (tahun) } \\
\hline - Jantan & $3,15 \pm 3,65$ \\
\hline - Betina & $8,8 \pm 3,56$ \\
\hline 6. $\quad$ Umur pertama beranak (bulan) & $31,97 \pm 6,43$ \\
\hline 7. Jarak beranak (calving interval) (bulan) & $14,56 \pm 2,15$ \\
\hline \multicolumn{2}{|l|}{ 8. $\quad$ Persentase kelahiran } \\
\hline - $\quad$ Terhadap induk & 51,66 \\
\hline - $\quad$ Terhadap populasi & 30,19 \\
\hline \multicolumn{2}{|l|}{ 9. $\quad$ Rasio kelahiran $(\%)$} \\
\hline - Jantan & 48,62 \\
\hline$-\quad$ Betina & 51,38 \\
\hline \multicolumn{2}{|l|}{ 10. Cara perkawinan } \\
\hline - Kawin alam & $100 \%$ \\
\hline - $\quad$ Inseminasi buatan & $0 \%$ \\
\hline \multicolumn{2}{|l|}{ 11. Umur paling tua digunakan (tahun) } \\
\hline - Jantan & $6,0 \pm 3,74$ \\
\hline - $\quad$ Betina & $12,32 \pm 3,77$ \\
\hline \multicolumn{2}{|l|}{ 12. Kondisi induk setelah beranak } \\
\hline - Gemuk & $7,5 \%$ \\
\hline - $\quad$ Sedang & $23,7 \%$ \\
\hline - $\quad$ Kurus & $68,8 \%$ \\
\hline
\end{tabular}

Keterangan: Jumlah responden 108 orang dan jumlah sapi 361 ekor

apabila kurang dari 27 bulan maka nilai ER akan lebih dari $100 \%$

\section{Pertambahan Alami (Natural Increase)}

Nilai NI diperoleh dengan mengurangkan tingkat kelahiran dengan tingkat kematian dalam suatu wilayah tertentu dan waktu tertentu yang biasanya penghitungannya diukur setiap tahun (Sumadi et al., 2001). Penentuan kategori NI dilakukan dengan melihat persentase populasi induk terhadap populasi, dari persentase tersebut kemudian dibagi tiga untuk pengkategorian tinggi, sedang, dan rendah. Nilai NI tertinggi dapat diperoleh apabila seluruh induk dalam populasi beranak dan tidak terdapat kematian pedet (Kusuma et al., 2017).

Perhitungan natural increase (NI) sapi Madura di Pulau Sapudi tahun 2014 tersaji pada Tabel 2. Nilai NI sapi Madura sebesar 27,96\%. Hasil ini lebih tinggi dari sapi Madura di Pulau Madura tahun 1992 sebesar 18,26\% (Maskyadji, 1992) atau yang dilaporkan BPPP (1992) yakni natural increase $18 \%$ pertahun. Begitupula jika dibandingkan dengan NI sapi potong breed yang berbeda oleh Samberi (2010) 18,18\%, Putra et al. (2015) 29,46\%, Aminuddin (2005) 25,30\%, Sulistia (2007) 22,02\%. NI sapi Madura di wilayah Pulau Sapudi tersebut menunjukkan bahwa dengan 58,45 persen

Tabel 2. Perhitungan natural increase sapi Madura di Pulau Sapudi

\begin{tabular}{llc}
\hline \hline No & \multicolumn{1}{c}{ Uraian } & Rataan \\
\hline 1 & Persentase betina dewasa (\%) & 58,45 \\
2 & Kelahiran pedet terhadap betina dewasa & 51,66 \\
3 & Kelahiran pedet terhadap populasi (\%) & 30,19 \\
4 & Tingkat kematian ternak terhadap populasi & 2,23 \\
5 & Natural increase & 27,96 \\
\hline
\end{tabular}

Sumber: Data Primer (2014) 
Tabel 3. Nilai net replacement rate sapi Madura di Pulau Sapudi tahun 2014

\begin{tabular}{clc}
\hline \hline Sex & \multicolumn{1}{c}{ Uraian } & Persen (\%) \\
\hline Jantan & Ramalan jantan muda yang hidup umur 2 tahun (\%) & 13,59 \\
& Kebutuhan jantan pengganti (\%) & 14,13 \\
& Net replacement rate (\%) & 96,18 \\
Betina & Ramalan betina muda yang hidup umur 2 tahun (\%) & 14,36 \\
& Kebutuhan induk pengganti (\%) & 11,36 \\
& Net replacement rate (\%) & 126,41 \\
\hline
\end{tabular}

Sumber: Data primer, 2014

betina dewasa yang tersedia, diperoleh kelahiran pedet terhadap populasi sebesar 30,19\%, dengan tingkat kematian mencapai 2,23\%. Pertambahan populasi sapi Madura secara alami tersebut dapat menghasilkan tambahan pedet 51,66\%. Nilai NI tersebut menunjukkan bahwa pertambahan populasi sapi tergolong sedang (tinggi : 38,98 sampai 58,45\%; sedang : 19,49 sampai 38,97\%; rendah : 0 sampai 19,48\%).

\section{Net Replacement Rate}

Nilai net replacement rate (NRR) diperoleh dari perbandingan jumlah ternak muda calon pengganti dengan kebutuhan ternak pengganti per tahun dikalikan $100 \%$. Nilai NRR digunakan untuk mengetahui apakah jumlah kelahiran ternak dapat menutupi kebutuhan akan ternak pengganti agar populasi tetap konstan. Dalam hal ini NRR $<100 \%$ maka kebutuhan ternak pengganti tidak terpenuhi, sebalik-nya bila NRR $>100 \%$ maka kebutuhan ternak pengganti tercukupi (Samber et al., 2010).

Nilai NRR sapi Madura di Pulau Sapudi tahun 2014 tersaji pada Tabel 4. Dari Tabel tersebut dapat dilihat bahwa ramalan sapi jantan muda dan betina yang hidup umur 2 tahun masing-masing 13,59\% dan $14,36 \%$, kebutuhan pengganti masing-masing $14,13 \%$ dan $11,36 \%$. Nilai NRR sapi jantan dan betina masingmasing $96,18 \%$ dan $126,41 \%$. Ini mengidentifikasikan kebutuhan pengganti ternak jantan tidak terpenuhi, sementara sapi betina terdapat kelebihan 26,41\%. Dugaan faktor penyebabnya adalah tujuan pemeliharaan ternak diatas $90 \%$ untuk pembibitan sedangkan tujuan penggemukan dibawah $3 \%$. Mayoritas peternak akan menjual pedet lepas disapih terkecuali pedet betina dengan performan bagus yang akan dijadikan induk pengganti. Tindakan tersebut dilakukan untuk mengurangi jumlah pakan yang harus disediakan, dimana ketersediaan pakan minim terutama pada musim kemarau.

Keterbatasan lingkungan sebagai faktor pembatas yang mengharuskan mereka lebih mengkhususkan untuk menghasilkan pedet daripada pembesaran atau penggemukan. Tiap tahun pengeluaran sapi didominasi oleh kategori usia pedet dan ternak muda, dengan kondisi induk setelah beranak sebagian kurus. Dari pembibitan mereka mendapat untung minimal Rp. 3-4 juta setiap 12-16 bulan/ekor. Hadi et al. (2002), usaha pembibitan sapi potong secara finansial jauh lebih kecil dibandingkan usaha penggemukan.

Pada musim kemarau ketersediaan pakan sangat minim, namun keuletan dan tradisi yang mendarah daging dalam kehidupan peternak sehingga mereka bisa bertahan dan tetap mampu menghasilkan pedet setiap 12-16 bulan. Saat ini hal yang paling dibutuhkan di Pulau terisolir ini adalah pakan, melalui upaya peningkatan produktivitas dan kuantitas tanaman pakan yang tahan terhadap kekeringan. Di samping itu para peternak sangat mengharapkan infrastruktur yang mendukung ketersediaan air. Winarso et al. (2005) menyarankan pengembangan teknologi pakan terutama pada basis wilayah padat ternak. Siswijono et al. (2014)

Tabel 4. Potensi atau output sapi Madura di Pulau Sapudi

\begin{tabular}{|c|c|}
\hline Uraian & Persen (\%) \\
\hline Sex rasio kelahiran (jantan : betina) & $48,62: 51,38$ \\
\hline Jumlah anak yang dilahirkan & 13,59 \\
\hline - Jantan & 14,36 \\
\hline - Betina & \\
\hline \multicolumn{2}{|c|}{ Jumlah sapi pada umur 2 tahun berdasarkan angka kematian ternak muda } \\
\hline - Jantan & 13,74 \\
\hline - Betina & 14,52 \\
\hline \multicolumn{2}{|l|}{ Kebutuhan ternak pengganti } \\
\hline - Jantan & 14,13 \\
\hline - Betina & 11,36 \\
\hline \multicolumn{2}{|l|}{ Sisa replacement stock } \\
\hline - Jantan & 5,26 \\
\hline - Betina & 18,01 \\
\hline \multicolumn{2}{|l|}{ Persentase ternak afkir } \\
\hline - Jantan & 14,13 \\
\hline - Betina & 11,36 \\
\hline
\end{tabular}




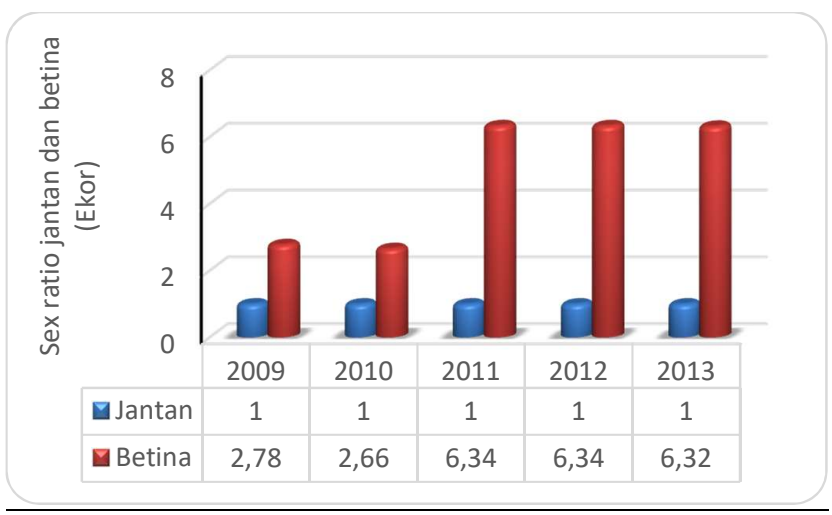

Gambar 1. Sex ratio sapi jantan dan betina dalam kurun waktu 2009-2013 di Pulau Sapudi. Sumber: Data Dinas Peternakan Sumenep (2014)

menyarankan bahwa pengembangan kelembagaan konservasi sapi Madura harus memenuhi ketentuan yang terkait dengan aspek ekonomi, teknis dan sosial.

\section{Potensi Ternak}

Potensi sapi Madura di Pulau Sapudi adalah banyaknya ternak sapi yang dapat dikeluarkan untuk dikirim atau dipotong dari wilayah tersebut tanpa mengganggu kesinambungan populasinya. Tabel 4 menunjukkan bahwa potensi sapi Madura di Pulau Sapudi atau output setiap tahun tanpa mengganggu populasi yang ada, mencapai $30,75 \%$ setara dengan 12.663 ekor yang terdiri dari sisa replacement stock (jantan muda) sebesar 5,26\% setara dengan 2.166 ekor, jantan dan betina afkir masing-masing 14,13\% setara dengan 5.819 ekor dan $11,36 \%$ setara dengan 4.678 ekor. Selanjutnya betina muda sebesar $18,01 \%$ setara dengan 7.417 ekor dipersiapkan untuk pengembangan populasi.

Nilai output sapi madura di Pulau sapudi pada penelitian ini lebih tinggi daripada beberapa penelitian output sapi Bali atau sapi potong lainnya yaitu 13,11\% (Samberi et al., 2010), Tonbesi (2008) sebesar $21,72 \%$, Aminuddin (2005) yakni mencapai 25,05\%. Namun nilai output ini lebih rendah bila dibandingkan dengan hasil penelitian Kusuma et al. (2017) sebesar $39,73 \%$.

Potensi atau output sapi potong di suatu daerah adalah banyaknya ternak yang dapat dikeluarkan untuk dikirim atau dipotong dari suatu daerah tertentu tanpa mengganggu keseimbangan populasi ternak tersebut (Hardjosubroto, 1987 dalam Kusuma et al., 2017). Nilai output ternak sama dengan nilai NI-nya maka dapat dikatakan terjadi keseimbangan populasi sehingga dalam kata lain nilai output populasi ternak yang paling optimal adalah sama dengan nilai NI-nya. Apabila nilai output ternak lebih rendah daripada nilai NI-nya maka akan terjadi peningkatan populasi, sedangkan jika nilai output lebih tinggi daripada nilai NI maka telah terjadi pengurasan populasi (Kusuma et al., 2017). Hasil perhitungan output sapi madura di wilayah konservasi Pulau sapudi menunjukkan telah terjadi pengurasan populasi, yakni nilai output lebih tinggi daripada NI $(30,75 \%$ vs $27,96 \%$ ).

Seperti yang dijelaskan pada bagian sebelumnya bahwa Nilai net replacement rate (NRR) sapi jantan $96,18 \%$ yang menunjukkan bahwa kebutuhan ternak pengganti ternak jantan tidak terpenuhi 3,82\%. Berdasarkan data sekunder dalam kurun waktu lima tahun terakhir (Gambar 1) menunjukkan bahwa sex ratio jantan dan betina pada tahun 2009 mencapai 1 : 2,78; pada tahun 2010 terjadi sedikit penurunan dan mencapai $1: 2,65$; sementara dari tahun 2011- 2013 berubah menjadi $1: 6,3$, Artinya trend tiap tahun sex ratio jantan dan betina di wilayah ini semakin melebar. Faktor penyebabnya kemungkinan tiga hal. Pertama, ketersediaan dan pengolahan pakan sangat terbatas sehingga sebagian besar sapi yang dipelihara adalah sapi betina. Kutsiyah (2015) peternak menyiasati

Tabel 5. Dinamika populasi sapi madura dalam kurun waktu 2009 sampai 2013 di Pulau Sapudi

\begin{tabular}{ccrr}
\hline \multirow{2}{*}{ Tahun } & Populasi (ekor) & \multicolumn{2}{c}{ Perkembangan (\%) } \\
\cline { 3 - 4 } & & ekor & $\mathbf{( \% )}$ \\
2009 & 45.456 & & 1,94 \\
2010 & 46.337 & 881 & $-13,73$ \\
2012 & 39.977 & -6.360 & 1,05 \\
2013 & 40.397 & 420 & 1,94 \\
2014 & 41.182 & 785 & $-2,57$ \\
\hline Rataan & 40.121 & -1.061 & $-2,27$ \\
\hline
\end{tabular}

Sumber. Data Dispet Sumenep (2014) dan BPS (2015a; 2015b) 
Tabel 6. Estimasi dinamika populasi sapi madura dalam kurun waktu 2015 sampai 2019 di Pulau Sapudi

\begin{tabular}{cccc}
\hline \hline \multirow{2}{*}{ Tahun } & \multirow{2}{*}{ Populasi (ekor) } & \multicolumn{2}{c}{ Perkembangan (\%) } \\
\cline { 3 - 4 } 2015 & 42.245 & 2.124 & $\mathbf{( \% )}$ \\
2016 & 41.649 & -596 & 5.29 \\
2017 & 41.053 & -596 & -1.41 \\
2018 & 40.457 & -596 & -1.43 \\
2019 & 39.861 & -596 & -1.47 \\
\hline Rataan & 40.713 & -52 & $-0,09$ \\
\hline
\end{tabular}

persediaan pakan hanya dengan menumpuk ilalang dan sebagian limbah pertanian digantung di atas pohon, sebagian lagi di simpan diatas bubungan kandang. Kedua, musim tidak memberi kepastian, seringkali musim kemarau jauh lebih panjang sehingga kesulitan pakan. Ketiga, peterna meminumkan resiko yang dihadapi dengan memilih pembibitan karena lebih aman dari ketidak pastian dan resiko. Merujuk penelitian Heryadi (2010) biaya yang dikeluarkan untuk pemeliharaan sapi madura untuk penggemukan Rp. 570.000 per bulan sementara Kutsiyah (2009) biaya yang dikeluarkan untuk pemeliharaan sapi madura untuk pembibitan Rp. 260.000 per bulan (penghitungan ini menggunakan nilai nominal uang sehingga tidak memasukkan faktor inflasi).

Hasil penelitian terkini terkait imbangan jumlah populasi antara sapi madura jantan : betina, sepengetahuan penulis belum ada. Data yang tersedia yaitu hasil pengamatan tahun 1992 dari BPPP (1993), bahwa imbangan jumlah populasi antara sapi madura jantan : betina dewasa sekitar 1 : 3-4. Hal tersebut diduga karena tidak adanya persebaran yang proporsional antara sapi jantan dan betina dewasa, sehingga diberbagai wilayah peternak mengalami kesulitan mendapatkan pejantan unggul saat sapi induk mengalami birahi. Ini menunjukkan bahwa imbangan jantan dan betina di Pulau Sapudi jauh lebih tinggi yakni $1: 6,3$.

Dinamika Populasi Sapi Madura di Pulau Sapudi Dinamika populasi sapi Madura di Pulau Sapudi dalam rentang waktu tahun 2009 sampai 2014 mengalami penurunan tiap tah un sebesar $-2,27 \%$. Penurunan populasi sangat tinggi terjadi pada tahun 2011 yakni sebesar $-13,73 \%$. Hal tersebut kemungkinan disebabkan oleh keengganan peternak untuk menambah jumlah kepemilikan sapi. Pada kurun waktu 2009-2010 harga sapi mengalami penurunan drastis dimana harga pedet per ekor hanya Rp. 500.000,00 hingga Rp. 1.500.000,00. Kompas (2010a; 2010b; 2010c) Awal tahun 2010 terjadi kekacauan dalam struktur perdagangan daging dan sapi potong, serta kondisi tersebut diperparah karena impor sapi illegal. Ini menyebabkan harga sapi potong ditingkat peternak turun, sehingga bisa menjatuhkan semangat peternak karena mendistorsi pasar. Kutsiyah (2012a) awal tahun 2010 penurunan harga tiap ekor sapi Madura rata-rata sekitar 1,5 juta per ekor.
Peningkatan populasi terjadi pada tahun 20122013 sebesar 1,05-1,94\%. Kutsiyah (2015) antara tahun 2012-2014, harga satu ekor pedet di Pulau Sapudi kisaran Rp. 2.000.000 - 5.000.000. Peningkatan harga tersebut memberi gairah masyarakat untuk menambah ternak peliharaannyat. Lazim di Pulau ini suami istri memiliki kandang (barung) masing-masing secara terpisah dengan jumlah kepemilikan 3 hingga 5 ekor per barung.

Berdasarkan kenaikan rerata dan persamaan regresi $\mathrm{Y}=\mathrm{aX}+\mathrm{b}$ dari hasil analisis time series data tahun 2009 sampai 2014, diperoleh persamaan $\mathrm{Y}=$ 42.245 - 596X selanjutnya digunakan untuk mengestimasi populasi sapi di Pulau Sapudi tahun 2015 sampai tahun 2019. Seperti tersaji pada Tabel 6.

\section{KESIMPULAN}

S/C $1,68 \pm 0,87$ kali, jarak beranak $14,56 \pm 2,15$ bulan, dan nilai efisiensi reproduksi (ER) 93,21\%. Nilai natural increase (NI) sapi Madura di Pulau Sapudi tahun 2014 sebesar 27,96\%, nilai net replacement rate (NRR) sapi jantan dan betina masing-masing sebesar $96,18 \%$ dan $126,41 \%$. Hasil estimasi output sapi PO $30,75 \%$. Output setiap tahun tanpa mengganggu populasi yang ada setara dengan 12.663 ekor terdiri dari sisa replacement stock (jantan muda) sebesar 5,26\%, ternak afkir masing-masing jantan 14,13\% dan betina $11,36 \%$. Dinamika populasi sapi Madura di Pulau Sapudi dalam kurun waktu tahun 2009 sampai 2013 mengalami penurunan rerata setiap tahun sebesar $2,27 \%$. Hasil estimasi dinamika populasinya tahun 2015 sampai 2019 diperkirakan akan menurun 599 ekor atau $-0,09 \%$ per tahun. Disimpulkan bahwa di wilayah konservasi sapi madura Pulau Sapudi telah terjadi pengurasan populasi, yakni nilai output lebih tinggi daripada NI (30,75\% vs 27,96\%). Di samping itu jumlah kebutuhan ternak pengganti sapi jantan tidak terpenuhi, kondisi ini ditunjukkan dari trend tiap tahun sex ratio jantan dan betina semakin melebar. Oleh karena itu tindakan selayaknya dilakukan adalah mengurangi pengeluaran ternak khususnya sapi jantan dan menyediakan infrastruktur yang mendukung hal tersebut, salah satunya yang paling dibutuhkan saat ini adalah ketersediaan infrastruktur pakan dan infrastruktur yang mendukung ketersediaan air. 


\section{DAFTAR PUSTAKA}

Aminudin, A. 2005. Estimasi Dinamika Populasi dan Potensi Sapi Bali di Provinsi Sulawesi Tenggara. Tesis. Program Pascasarjana Peternakan. Universitas Gadjah Mada. Yogyakarta.

BPPP (Badan Penelitian dan Pengembangan Peternakan). 1992. Rumusan Hasil Pertemuan Ilmiah Hasil Penelitian dan Pengembangan Sapi Madura. Pros Pertemuan Ilmiah Hasil Penelitian dan Pengembangan Sapi Madura. Sub Balitnak Grati. Sumenep. hlm. ix-xiii.

BPS. 2015a. Kecamatan Gayam dalam Angka Tahun 2015.

BPS. 2015b. Kecamatan Nonggunong dalam Angka Tahun 2015

BPS. 2016a. Kecamatan Gayam dalam Angka Tahun 2016.

BPS. 2016b. Kecamatan Nonggunong dalam Angka Tahun 2016.

Deptan. 1998. Tanggapan pemasukan sapi ke Pulau Madura. Balitbang Pertanian. Puslitbang Peternakan. Deptan

Dinas Peternakan Provinsi Jawa Timur. 2012. Pengembangan Peternakan di Madura. Focus Group Discussion Potensi dan Peluang Pengembangan Ternak di Pulau Madura. Sumenep 20 Juni.

Dinas Peternakan Sumenep. 2014. Populasi Ternak Sapi Tahun 2009-2014. Dinas Peternakan Sumenep. Tidak dipublikasikan

Efendy, J dan Mariyono. 2013. Keberhasilan kebuntingan pada sapi Madura melalui penerapan kawin alam. Seminar Nasional Teknologi Peternakan dan Veteriner 2013

European Commission, 1992. Council regulation No. 2078/92 of June 1992. Official Journal of European communities L215, 85-9; with coite des structures agricoles et de development Rural (STAR) working document VI/5404/92.

FAO (Food and Agriculture Organization). 1995. World Watch List for Domestic Animal Diversity, second ed., p. 769 (Rome, Italy)

Hadi, P.U dan N Ilham. 2002. Problem dan prospek pengembangan usaha pembibitan sapi potong di Indonesia. Jurnal Litbang Pertanian.

Hardjosubroto, W., B. Endang, dan Z. Sidqi. 1993. Kapasitas suplai sapi Madura dari pulau Madura. Pros. Pertemuan Ilmiah Hasil Penelitian dan Pengembangan Sapi Madura. Sub Balitnak Grati. Sumenep. 198-210.

Heryadi, A. Yudi. 2010. Bisnis Penggemukan (Fattening) Sapi Madura Di Kabupaten Pamekasan. Tesis. Program Pascasarjana. Universitas Pembangunan Nasional Veteran. Surabaya.

Kompas. 2010a. Harga Sapi Merosot. Kompas, sabtu, 5 Februari.
Kompas. 2010b. Impor 2.150 Sapi Ilegal. Kompas, 2 Juli.

Kompas. 2010c. Menunda Penjualan Sapi. Bisnis dan keuangan, Kompas, Kamis, 6 Juli.

Kusuma, S.B., N. Ngadiyono, dan Sumadi. 2017. Estimasi dinamika populasi dan penampilan reproduksi sapi Peranakan Ongole di Kabupaten Kebumen Provinsi Jawa Tengah. Buletin Peternakan Vol. 41 (3): 230-242, Agustus 2017. Bulletin of Animal Science, DOI: 10.21059/buletinpeternak.v41i3.13618

Kutsiyah, F. 2009. Analisis kinerja program bantuan pinjaman langsung masyarakat melalui lembaga pesantren di Madura. Jurnal Agro Ekonomi (JAE), Pusat Analisis Sosial Ekonomi Dan Kebijakan Pertanian, Puslitbang Bogor. Volume 4 Nomor 1/2009:109-134

Kutsiyah, F. 2012a. Kelembagaan dan Pembibitan Sapi Potong di Pulau Madura. Karya Putra Darwati, Bandung.

Kutsiyah, F. 2012b. Analisis Pembibitan Sapi Potong di Pulau Madura. Wartazoa, Bulletin Ilmu Peternakan dan Kesehatan Hewan Indonesia, Puslitbang Peternakan, Bogor. Volume 22 nomor 3:113-126.

Kutsiyah, F. 2015a. Sapi Sonok dan Karapan Sapi: Budaya Ekonomi Kreatif Masyarakat Madura. Plantaxia, Yogyakarta.

Maskyadji, Z.Z.S.A. 1992. Pertumbuhan dan Output Sapi Madura di Pulau Madura. Tesis. Program Pascasarjana. Universitas Gadjah Mada. Yogyakarta.

Putra, D.E., Sumadi dan T. Hartatik. 2015. Estimasi output sapi potong di Kabupaten Pesisir Selatan Provinsi Sumatera Barat. Jurnal Peternakan Indonesia, Juni. Vol. 17 (2).

Samberi, K.Y., N. Ngadiyono, dan Sumadi. 2010. Estimasi dinamika populasi dan produktivitas sapi Bali di Kabupaten Kepulauan Yapen, Propinsi Papua. Buletin Peternakan 34: 169-177. DOI: 10.21059/buletinpeternak.v34i3.87.

Siswijono, S.B, V.M.A. Nurgiartiningsih dan Hermanto. 2014. Pengembangan Model Kelembagaan Konservasi Sapi Madura. Jurnal Ilmu-Ilmu Peternakan. 24: 33 - 38.

Sulistia, I. 2007. Estimasi Natural Increase dan Pola Pemeliharaan Sapi Bali di Kabupaten Penajam Paser Utara, Kalimantan Timur. Skripsi. Fakultas Peternakan Universitas Gadjah Mada. Yogyakarta. Sumadi. 2001. Estimasi dinamika populasi dan output kambing Peranakan Ettawah di Kabupaten Kulon Progo. Buletin Peternakan 25: 161-171.

Sumadi, W. Hardjosubroto, N. Ngadiyono, dan S. Prihadi. 2001. Potensi Sapi Potong di Kabupaten Sleman. Analisis dari Segi Pemuliaan dan Produksi Daging. Yogyakarta.

Tonbesi, T.T. 2008. Estimasi Potensi dan Kinerja Sapi Bali di Kabupaten Timor Tengah Utara Propinsi Nusa Tenggara Timur. Tesis. Pascasarjana Universitas Gadjah Mada. Yogyakarta. 
Winarso, B., R. Sajuti dan C. Muslim. 2005. Tinjauan Ekonomi Ternak Sapi Potong di Jawa Timur. Forum Penelitian Agro Ekonomi. 23:61-71.

Wisono, D.A. 2015. Performan Reproduksi Sapi Madura Induk dengan Perkawinan Inseminasi Buatan di Kabupaten Pamekasan. Thesis, Universitas Brawijaya. 